\title{
Conrad's Efficiency in An Outpost of Progress
}

\author{
Daisy Ariesta \& Emanuella Christine Natalia Mau \\ Daisyars132@gmail.com \& Emanuellamau@gmail.com \\ Universitas Kristen Krida Wacana, Jakarta
}

\begin{abstract}
This study aims at finding out Conrad's efficiency in An Outpost of Progress. The efficiency itself means the characteristic of being human which is found in Conrad's An Outpost of Progress that is directed on how white people should act. The main character of this story is analyzed using the theory of character The theory of author and voice is used to crosscheck the findings in theory of characters. These theories contribute to find out Conrad's voice in the story.

This study finds out that Conrad is emphasizing the importance of efficiency to white men. This study also supports Achebe's statement toward Conrad being a racist. It is because Conrad is proud of having the efficiency and is looking down at the other race.
\end{abstract}

Keywords: Efficiency, Joseph Conrad, An Outpost of Progress

\section{Introduction: Marxism, Social Darwinism, and Colonialism}

The breakthrough of capitalism in the $18^{\text {th }}$ century made capitalism paradigm spread through the 19th century. It was originally started in Britain as the first industrial society. By the mid 19th century, most people in Britain started to make their living from mining or manufacturing industries as engines started to be improved (Lambert, 2017). People in Britain have been divided into classes and at this time the bourgeois (middle class people) increase in number. The capitalism was spreading widely because of the merchants. These merchants had begun their international trade through the world. The high demand from the market forced the owner of the production house to monopolize the employees' wages and production fees in the upcoming time while pressing down the production fees as low as possible. Because of this reason too, the rate of exploitation increased. Britain was searching for raw materials. Britain and the other European countries were lacking of self-sufficiency raw material, and other domestic raw materials were expensive. This matter was taken abroad to Africa and Asia, and the expedition started. Product became a commodity for people. After some time the market was stagnant throughout the country. In order not to experience a big loss over money that could lead into bankruptcy, the merchants had to find a new available market. The thought of selling goods to other country emerged in this state. This became one of the reasons to colonize other countries, not only to get the materials, but also to fix the economy and spread the country's production (Scott, 2011; Fulcher, 2004; Wayne, 1981).

The ideology of Capitalism and Marxism cannot be separated from colonialism. The idea of Capitalism leads to the theory of Marxism which both exist because of the market demands. Domestic raw materials were expensive at that time so employees' wages were pushed down to a minimum concerning the profit they would gain. Because of this, Marxism occurred. Marxism is an ideology which stands for proletarians (working class people) in order to make the people, proletarians or the bourgeois, of a country get the equal wages and no one being 
poor or struggle in term of economy (Marx \& Engels, 1969). In other words, Marxism wants the equality for a country's people and the way to make this equality occurs is the citizen has to have the same wages based on their hard working, not because of the power of an individual has (Lukacs, 1971). Britain is a capitalist country. The reason behind the Africa colonialism is because of the natural source that becomes a demand in the market. Marxism is used to fight against the inequality that people get when the ideology of capitalism is used.

The expedition abroad to Africa and Asia is not only supported by the market demands for the product which result in colonialism. This ideology is strengthened by the Social Darwinism. This theory of evolution was proposed by Charles Darwin and had become the underlying thought on human and race. Later, the theory is called Darwinism. This theory explains the natural selection that makes the weak species unable to survive against the fully developed species (Prien, Pitts, \& Kamery, 2003). This theory was proven by the beaks of the birds in Galapagos Island that changed it physiology because they were trying to survive and adapt in the different environment (Lamichhaney et al., 2015).

The term survival of the fittest was popularized by Herbert Spencer. This term was the reason for Social Darwinism to rise in the late 19th century. Social Darwinism is one of the traits of Darwin's theory of evolution though it used human as the subject. They believed that human was also competing in order to survive. This basic thought becomes the justice for the harsh social policies, not only in Britain but also in other countries. British concluded that they were the fittest in the competition. Their race was superior to the others so it was right for them to rule over the other nations and societies (Lewis, 2016).

Many literary works talked about colonialism as the popular theme amongst society in the $18^{\text {th }}$ century. Colonialism itself is defined as a form of domination over another group or country and exploitation of the culture (Ashcroft, Griffiths, \& Helen, 2007; Horvath, 1972). One of the famous authors in colonialism era is Joseph Conrad. Some of his works that used colonialism as the theme are An Outpost of Progress and Heart of Darkness. The setting of An Outpost of Progress and is Asia when Britain was colonizing the countries there. Ambiguities in interpreting Joseph Conrad's implied messages in his works make them become distinctive (Snoubar, 2017).

Although Conrad tends to degrade the natives who are African and Asian in his works, he also praises them. "... She was savage and superb, wild-eyed and magnificent; there was something ominous and stately in her deliberate progress. ..." (Conrad, 1899: 101). Marlow describes an African woman as savage and superb. As defined by Oxford Advanced Learner's Dictionary (2015: 1332), in general savage means "aggressive and violent" while the connotative meaning of it is "an offensive way to refer a group of people who are not well developed". On the other hand, Conrad also describes the woman as superb which is defined as "excellent or of very good quality" (Hornby, 2015: 1518). The word savage obviously has a negative connotation while the word superb is positive. Because of the way of his description, Conrad is understood as a racist (Snoubar, 2017).

However, Hawkins views Conrad as a person who was against colonialism. In Conrad's Critique of Imperialism in Heart of Darkness (Hawkins, 1979), Hawkins says that Conrad is actually supporting imperialism. Hawkins interprets that Conrad needs to make his works accepted by the European. In order to do so, Conrad implicitly puts his message between the lines.

Summarizing the thoughts above, it can be concluded that Conrad has his own standards of human which later is termed as "efficiency". Therefore, it is significant to explore and discover Conrad's efficiency in his work, $A n$ Outpost of Progress.

This efficiency is mentioned and discussed in Snoubar's Joseph Conrad's Heart of Darkness: Debunking the Two Basic Imperial Clichés. Basically, this efficiency refers to the value of being human. This efficiency is supported by Social Darwinism which is emerged because of Darwinism, a theory about evolution, 
proposed by Charles Darwin. For example, the bird's beaks were changed in Galapagos Island as a response to environmental changes (Lamichhaney et al., 2015). This theory is used and adapted by Social Darwinism, using human as the subject. The "survival of the fittest" phrase then occurred and was popularized by Herbert Spencer (Prien et al., 2003). Meanwhile, in Kennedy's Conrad, Efficiency, and the Varieties of Imperialism (2012), efficiency is the characteristic for being English. The meaning of efficiency in this study is the characteristic that the author, Joseph Conrad, wants people to have.

This study is expected to give a better critical analysis and understanding towards the issue of inequality in the society. Other than that, this paper also aims at clarifying any inequality issues triggered by races and beliefs. There is nothing such as the standard for people, as people have their own unique characteristics which are formed by their surrounding, their race, their belief, and other aspects.

\section{Methodology}

The story was read and any possible data for Conrad's ideal efficient character in the form of dialogue, action, or description was taken and noted based on the theory of character, author, and voice (Bennett \& Royle, 2016). The plot, the interplay between one and another, and the event that happen in the story were also considered as the data that supported the characters as they showed how the characters reacted to them. The next step was interpreting the voice of Joseph Conrad concerning the efficiency based on the three theories (character, voice, and author), using Darwinism, Social Darwinism, and Marxism as the ground theories which to slice up the story's events at that time. Finally, the conclusion was drawn and Conrad's value of efficiency was stated to answer the question.

\section{Analysis}

An Outpost of Progress is a part of Tales of Unrest that includes other five short stories by Joseph Conrad, It was published in 1898. This short story focuses on three characters which are Kayerts, Carlier, and Makola. The setting of the story is Africa. An Outpost of Progress uses the third person point of view.

The opening of the story directly mentions two white men: Kayerts and Carlier. There is no further description about them other than that Kayerts is short and fat and he is the chief of the trading system; Carlier is tall and has a large head and a very board trunk perched upon a long pair of his thin legs. Makola, a black man, is described quite in details. Conrad also tells about Makola's family, his wife and his three children. Makola is said to be taciturn and impenetrable, despised the two white men, Kayerts and Carlier (Conrad, 1896: 1).

Defined by Oxford Advanced Learner's Dictionary, the word taciturn means tending not to say very much, in a way that seems unfriendly; while the first meaning of impenetrable is "that cannot be entered, passed through, or seen through". However, the word impenetrable that is used to describe Makola means "impossible to understand", as defined by Oxford Dictionary as the connotation.

In the same paragraph, Kayerts and Carlier are also described as messy persons. Near the station they are assigned to, there is a house that has three rooms, two for the white men and the other one for Makola. The description of the white men's rooms shows that Kayerts and Carlier are careless. There are many of their things scattered on the floor such as halfopen boxes, torn wearing clothes, and old boots. All of their belongings are dirty and Conrad emphasizes that Kayerts and Carlier are round untidy men. Once again, Makola is said to be the opposite who is, as usual, quiet diligent.

Kayerts and Carlier are assigned to be in charge of a trading station. As the director said while looking at Kayerts and Carlier from his deck:

"Look at those two imbeciles. They must be mad at home to send me such specimens. I told those fellows to plant a vegetable garden, build a new storehouses and fences, and construct a landing-stage. I bet nothing will be done! I always thought the 
station on this river useless, and they just fit the station!" (Conrad, 1896: 2)

The director seems to have no choice other than letting the beginners to be in charge, with the word 'beginners' directed to Kayerts and Carlier. It can be concluded that Kayerts and Carlier are two useless men, the same as the useless station. They can do nothing except the easy and quite useless tasks. The white men are also touched by the director when the director says that the job is very promising and it is a favor from him to Kayerts and Carlier. It also means that they are kind of persons that can be easily manipulated. But it is, indeed, just a sweet word for Kayerts and Carlier, as at the first, the director keeps his eyes on them, but after some times, they are left unassisted in an unknown land.

Another description for Kayerts and Carlier which is directly stated is they are perfectly insignificant and incapable individuals. Insignificant means not big or valuable enough to be considered important while incapable means not able to do something (Hornby, 2015). These two adjectives emphasize the previous description about Kayerts' and Carlier's being useless.

These descriptions about Kayerts and Carlier will later be a problem for themselves as there is a continuation after Conrad describes those two white men as insignificant and incapable.

...,whose existence is only rendered possible through the high organization of civilized crowds. Few men realize that their life, the very essence of their character, their capabilities and their audacities, are only the expression of their belief in the safety of their surroundings (Conrad, 1896: 2-3).

It can be interpreted from this description that although European countries are superior to the others (as they are civilized), they still have citizens like Kayerts and Carlier. These men think that they live in a comfortable world so that they live carelessly. The outstanding characteristics such as courage, composure, confidence, emotion and principles, belong to the society; not to the individuals. This dark country is a burden for him. "But the contact with pure unmitigated savagery, with primitive nature and primitive man, brings sudden profound trouble into the heart" (Conrad, 1896: $3)$.

They don not have any assistance; they only have each other. They are described as 'useless' as they walk hand in hand in the dark when passing the grave of the chief. As they are assigned to this dead chief, Makola says that the previous chief died because of fever. As the chief, Kayerts warns Carlier not to be exposed under the sun because the climate in Africa is quite extreme. Being together makes them cherish each other. "We shall let life run easily here! Just sit still and gather in the ivory those savages will bring. This country has its good point, after all!" (Conrad, 1896: 3). These words show how ignorant and carefree life is for them. They even clean up their house to be habitable and pretty. Kayerts and Carlier are just unfit in the world that is full of struggle.

But the two men got on well together in the fellowship of their stupidity and laziness. Together did nothing, absolutely nothing, and enjoyed the sense of the idleness for which they were paid. ... They lived like blind men in a large room, aware only of what came in contact with them, but unable to see the general aspect of things (Conrad, 1896: 4).

So many works they do, but none of them is necessary. Until one day, visitors come. They are surprised by how these strangers speak incomprehensible language but it sounds like the speech of civilized men. They are easy to be pleased and this is one of Kayerts and Carlier's weaknesses. They are amazed by a language, just because it is unknown.

It seems that the visit from strangers delivers some senses to them. They start to feel uneasy in an unusual situation. Kayerts and Carlier intend to order Makola to ask the strangers to go. Makola agrees to send the strangers away but when it is asked by the white men, the black man feels strange. He seems to forget how to speak. Kayerts and Carlier, however, just think that Makola is drunk. Day by day, the white men start to realize that Makola acts queerly. 
Months have passed. The income of the ivory from Kayerts and Carlier's station decreases. These two white men are not doing their job well. Instead, they are busy taking care of the natives as if they were their children, something precious. It is described in the story that the natives are losing their splendid physique. They do a very little job and the white men have lost their control over the colored men. So, Makola asks twice whether they want the ivory or not. Kayerts and Carlier want the ivory but they do nothing. Until one day, an incident happens.

Makola is sly. He has been working at that station longer than Kayerts and Carlier. As the white men say they want the ivory, at the night after the conversation, Makola sells his men to the strangers that has come previously in order to get the ivory. After knowing what Makola does, Kayerts and Carlier are shocked. Kayerts, who cannot suppress his feeling, shouts to and threatens Makola that he will report it to the director. But Makola's anwer is surprising. "You are very red, Mr. Kayerts. If you are so irritable in the sun, you will get fever and die-like the first chief!" pronounced Makola impressively (Conrad, 1896: 12).

From what Makola has said, it seems that the death of the first chief is suspicious and is related to Makola. The black man's action creates hatred in the white men. At first, Kayerts and Carlier have a good relation with a tribe from the neighboring villages, but when they try to go to the tribe with a canoe, they receive shower of arrows.

Kayerts and Carlier's mind starts to corrupt. The uneasiness creeps into them. Carlier gets sick and the sickness gets worse. Nobody is there for them. They are left alone in that station. They start to blame everything. They even fight because of a simple matter. Kayerts and Carlier are sick of this country and its silence that is swallowing them. They are weak and desperate.

In the end, Kayerts kills Carlier. They are anxious and paranoid. They do not think about others, their own life is the most important one now. Due to his panic, Kayerts shots Carlier. Makola, who witnesses the incident, calmly approaches Kayerts who is still unstable.
Makola covers Charlier's death. Carlier dies with his right-eye blown up, but Makola says that Carlier died because of fever. This refers to the cause of the former chief's death.

He died of fever." Kayerts looked at him with stony stare. "Yes," repeated Makola, thoughtfully, stepping over the corpse, "I think he died of fever. Bury him tomorrow (Conrad, 1896: 19).

After that incident, Kayerts' mind is full of thoughts.

When the director finally comes to meet them, no one comes to greet. And when the director asks the people to find those useless white men, they can only find Kayerts' body. No one says whether Kayerts purposely hanged himself or he died in an accident when climbing from Carlier's grave.

It can observed that there are some highlight in Conrad's An Outpost of Progress. By showing Kayerts and Carlier's behavior, he wants to tell the weaknesses that the white men usually have. Eliminating these weaknesses will be a good thing to do. This weaknesses can be seen in Kayerts and Carlier. These two white men are careless. Not only that, Conrad described these two men as a burden, useless men. They did not have the sense of duty. The other weakness is their being dependent on others. Conrad has emphasized that Africa has given him burdens and he wants other white men to have the same empathy towards Africa.

\section{Conclusion}

For Conrad, white men have a duty to do. This duty should be finished and solved. Conrad sees and pities the uncivilized men. Making them civilized is one of his justice. He does not want the white men to think that everything is okay because they are white or because their country is strong. A duty is a duty, and white men cannot stay still and live their life carelessly as they have a burden on their shoulders. It seems that Conrad feels the duty to be an agent of change (for a better world) by promoting the efficiency in the characters. This duty is indirectly implied in Heart of Darkness. It is shown by Kurtz who 
only thinks about himself without considering the important task that is given to every white man.

Conrad is emphasizing the efficiency that he is proud of, and is looking down at the other values of the other races. It can be seen from the fate of each main character that has inefficient characteristic. Death is the result of those who have insufficient quality. For Conrad, the sense of duty is quality that every white man should know and hold, while efficiency is the complementary quality to fulfill the duty. He does not see colonialism as a bad practice. Instead, he wants the white men to have the same sense of duty as he does in order to finish the duty of civilization. This statement justifies Achebe's statement that Conrad is a racist throughout.

The Europeans believe that in order to survive in the world that is full of struggle, people should make some changes, like the beak of the birds in Galapagos Island. In this case, in order to survive, size dose matter. However, the recent research related to the human's fossil, Homo Floresiensis in Pleistocene cave at Liang Bua, Flores, Indonesia, finds out that this Homo Floresiensis has a smaller body within chimpanzee range, which is different from the other Homos. Homo Floresiensis is found with the complete set of tools such as weapons and other utensils for eating, which is as complete as the previous homo (Gagan et al., 2015; Brown \& Maeda, 2009). It can concluded that becoming bigger is not the indicator of being more civilized or more intelligent.

\section{References}

Ashcroft, B., Griffiths, G., \& Helen, T. PostColonial Studies: The Key Concepts. $2^{\text {nd }}$ Edition. New York: Routledge, 2007.

Bennett, A., \& Royle, N. An Introduction to Literature, Criticism, and Theory. $5^{\text {th }}$ Edition. New York: Routledge, 2016.
Brown, P., \& Maeda, T. Liang Bua Homo Floresiensis Mandibles and Mandibular Teeth: A Contribution to the Comparatie orphology of a New Hominin Species. Journal of Human Evolution. 2009, pp. 571-596.

Conrad, J. An Outpost of Progress. Gutenberg, 1896.

Conrad, J. Heart of Darkness. University of Virginia, 1899.

Fulcher, J. Capitalism: A Very Short Introduction. New York: Oxford University Press, 2004.

Gagan, M. K., Ayliffe, L. K., Smith, G. K., Hellstrom, J. C., Gagan, H. S., Drysdale, R. N., ... Djubiantono, T.

Geoaechaeological Finds Below Liang Bua (Flores, Indonesia): A Split-Level Cave System for Homo Floresiensis? Paleogeography, Paleoclimatology, Paleoecology. 2015, pp. 533-550.

Hawkins, H. Conrad's Critique of Imperialism in Heart of Darkness. PMLA. 1979, pp. 286-299.

Hornby, A. S. Oxford Advanced Learner's Dictionary of Current English. (L. Hey $\&$ S. Holloway, Eds.). $9^{\text {th }}$ Edition. Oxford: Oxford University Press, 2015.

Horvath, R. J. A Definition of Colonialism. Current Anthropology. 1972, pp. 45-57.

Kennedy, V. Conrad, Efficiency, and the Varieties of Imperialism. Conradiana. 2012, pp.163-189.

Lambert, T. "Daily Life in 18th Century

Britain." Localhistories.org. Localhistory.org, 2017. Web. (7 February 2018.)

Lamichhaney, S., Berglund, J., Almén, M. S., Maqbool, K., Grabherr, M., MartinezBarrio, A., ... Andersson, L. Evolution of 
Darwin's finches and their beaks revealed by genome sequencing. Nature. 2015, pp. 371-375.

Lewis, H. Social Darwinism: A Brief Outline of Social Darwinism and Its Influence on 19th Century Britain and Elsewhere. The Journal of Psychohistory. 2016, pp. 154161.

Lukacs, G. History and Class Consciousness: Studies in Marxist Dialetics. Great Britain: The MIT Press, 1971.

Marx, K., \& Engels, F. Manifesto of the Communist Party. Marx/Engels Selected Works. 1969, pp. 98-137.

Prien, K. O., Pitts, S. T., \& Kamery, R. H. The Rise and Fall of Social Darwinism in the Late 19th Century. Proceedings of the Academy of Organizational Culture, Communication and Conflict. 2003, pp. 51-56.

Scott, B. R. Capitalism: Its Origin and Evolution as a System of Governance. New York: Springer, 2011.

Snoubar, T. K. A. Joseph Conrad's Heart of Darkness: Debunking the two Basic Imperial Clichés. European Journal of English Language and Literature Studies. 2017, pp. 1-11.

Wayne, J. Capitalism and Colonialism in Late Nineteenth Century Europe. Studies in Political Economy. 1981, pp. 79-106. 